\title{
Partnership between the State and the Church: Contextualizing Nigerian Faith-Based Vehicles as Poverty Reduction Tools in the Millenium
}

\author{
Ani Casimir, Chukwuelobe Mathew, Ambrose Nwankwo \\ Department of Philosophy, University of Nigeria, Nsukka, Nigeria \\ Email: cepperngo@gmail.com, mchukwuelobe27@yahoo.co.uk
}

Received 14 January 2015; accepted 3 February 2015; published 5 February 2015

Copyright (C) 2015 by authors and Scientific Research Publishing Inc.

This work is licensed under the Creative Commons Attribution International License (CC BY). http://creativecommons.org/licenses/by/4.0/

(c) (i) Open Access

\begin{abstract}
Social scientists studying African development have found themselves in a "paradigmatic crisis" (Ake, 2003: p. 17) in recent years, especially in the face of new challenges of development arising from the millenium development goals adopted by the United Nations. They have often posed the question-How can African development benefit from the MDGS, so that the African poor can attain the goals before 2015 ? This crisis needs to be properly contextualized so as to understand the dilemma facing the African poor in the new millenium. For example, at the end of the day, we should be in a position to know the answers to such questions such as "who defines what is development in africa; what is under development; how do we develop ourselves; Who develops; who benefits from development and how do we measure development?" The Catholic Social Teachings have a recognized and documented role in alleviating the socio-economic and political development challenges facing the people. It was part of the thoeritical framework of this paper that the best strategy of incorporating the needs of the family is for the state to partner with the state to answer the challenges of development in Africa but also to embark upon practicable Family economic empowerment development strategy. But government in Nigeria fails to take this partnership seriously but came out with NEEDS-National economic empowerment development strategy; SEEDS-State economic empowerent development strategy; and LEEDS-Local government economic empowerment development strategy. In designing these development documents government solidly avoided the involvment of the church which is pro-people and pro-poor institution that had been committed to development concerns as part of its christian mandate. This paper, using the Catholic development chain model will seek to explain how the Church can increase the propeople impact of its development programs, to reduce poverty in Africa. To solve this dilemma, the paper introduces a new concept of Faith-based vehicles (FBVS) as the modem that will drive this partnership in development.
\end{abstract}

How to cite this paper: Casimir, A., Mathew, C., \& Nwankwo, A. (2015). Partnership between the State and the Church: Contextualizing Nigerian Faith-Based Vehicles as Poverty Reduction Tools in the Millenium. Open Journal of Political Science, 5, 58-67. http://dx.doi.org/10.4236/ojps.2015.52006 


\section{Keywords}

\section{NGOS, FBOS, FBVS, Poverty Reduction, NEEDS, SEEDS, LEEDS, FEEDS, Philosophy and Theory of Development}

\section{Introduction: Conceptual Analysis of Key Words and Poverty Reduction Frameworks}

For us to dialectically contexualize the use of faith based vehicles for poverty reduction, we need to delineate the meanings of the concepts hidden under these key words.

\subsection{NGO}

NGO stands for Non-governmenal organisation. Principally, Non-governmental organisations are civil society organisations managed by individuals that are not in government but are interested and committed to development concerns in the society. They are collectively known as members of civil society. They are seen essentially as the conscience of society who evaluate's government performance and to compliment, when they are given the chance, government's policy instruments aimed at developing the society. They are usually people-orientated.

\subsection{FBOS}

Religious institutions are members of the civil society; however, in an effort to distinguish and recognise their continuous contributions to development, they were traditionally and especially grouped as faith based organisations [FBOS] in the evaluation of civil society. So faith based organisations are religious NGOS with faith as their driving energy; mobilizing the energy of their faithfuls for development purposes. They use FBVS to drive and implement these development plans, programs, strategy and projects.

\subsection{FBVS}

The initials of this word stand for Faith-Based Vehicles. It was invented by myself in 1990 when I started exploring the dynamics of success stories recorded by churches and religious institutions who ventured into development projects for the social welfare and justice of not just their immediate members but also other members of the larger society. In point of fact, I wanted to see how far the church has been involved in poverty reduction in Nigeria before the expression became inflated with government propaganda and insincerity in policy execution. FBVS are projects designed and implemented with the sponsorship of the church or other religious groups that have a positive impact upon human development, leading to effective poverty reduction and the enhancement of social well being.

\subsection{Philosophy and Theory of Development}

Social scientists studying African development have found themselves in a "paradigmatic crisis" (Ake, 17-19) in recent years, especially in the face of new challenges of development arising from the millenium development goals adopted by the United Nations. They have often posed the question-How can African development benefit from the MDGS, so that the African poor can attain the goals before 2015? This crisis needs to be properly contextualized so as to understand the dilemma facing the African poor in the new millenium. For example, at the end of the day, we should be in a position to know the answers to such questions such as "who defines what is development in africa; what is under development; how do we develop ourselves; Who develops; who benefits from development and how do we measure development?"

The fundamental problem of our continent has been that these questions have been framed and defined for us by outsiders who enter the development equation with foreign interests that are not always pro-African people. The pro-western theory of development has attempted since the colonial period to answer these questions for africans with terrible consequences for the continent. 
We ought to know that the term paradigm signifies change from tradition and it is an academic problem that new challenging paradigms are not smoothly accepted without a debate or the aura of controversy. It was the philosopher Thomas Kuhn who made this word such a catch phrase in the history of philosophy in general and in the philosophy of science, specifically. At the end of the debate, Africans started questioning the philosophy and theory of development which had been initiated and used by the western scholars and philosophersin settling development problems in the continent. Actually, it was the emergence of dialectical issues in the natural sciences, and not the social sciences, that gave rise to the paradigm debate but it eventually dovetailed into the social sciences and maintained a living thrust in philosophy. For a refreshing thought, we may have to recall to mind his concept of the paradigm as captured by himself:

"a paradigm, according to him, consists of all the theoritical and methodological assumptions and operations which prevail in a period of a normal science during which scientists usually do not agree about their conclusions, once they are derived and tested within the rules of the prevailing paradigm. Meanwhile a number of empirical and theoritical anomalies may accumulate, however, which makes it impossible to retain that papradigm in the long run. Toward the end of such a paradigmatic crisis a 'scientific revolution' takes place and the old paradigm is replaced by a completely new one which ushers in a new period of 'norml science'... Disagreements and paradigmatic crisis seem to be the order of the day among the social sciences and they are often resolved, not by a khunian revolution, that is the emergence of a completely new paradigm, and the complete rejection of the old one-but rather by a search for a synthesis of perspectives where old ideas can be combined in a new manner”. (Hans, 1967: pp. 234-239)

In placing the search for a new philosophy and theory of development african social scientists came together and launched in 1994 what they defined as the "the search of new paradigms for the study of african development” (Ulf Himmelstrand et al., 1994: p. 1).

The result of such a search resulted in the acceptance of a new philosophy and theory for the study and the analysis of development as it pertains to the compehensive study of development in the social sciences:

[a] A specific selection of variables or objects of knowledge as it affects the african poor;

[b] A specific selection of analytical and empirical research methods;

[c] Choice of the kinds of praxis and applications favored'[khun].

It is becoming obvious that we have to go beyond the controversies and be concerned with the search for a "a new, more comprehensive, relevant and empirically sound approaches to the study of African development problems and challenges which could deliver the dividends of milenium development to the African poor.

This is what I call the new modernization theory of African indigenious development and it is well captured in my new book which I appropriately called philara—a new paradigm in relating philosophy to practical human situations and problems (Ani, 2012: pp. 1-4).

It is in the context of this new theoritical and philosophical clarity that we must redefine development, and, hence see our analysis of the NEEDS document which we have used for development planning in Nigeria between 1999 and 2007.

Most critically, it is within the context of this development framework that we must re-examine the role of the church in development in Nigeria; to understand why the exclusion of the church in dvelopment planning and policy formulation has led to such collossal failure and the worsening of the poverty situation in Nigeria. We must note that all over the globe, social scientists, especially philosophers of development, in keeping with the spirit of the old paradigm, took their lead from shifts in development theory, from structural functionalism and modernization [1950s]; then from neo-marxist political economy, and then, from neo-liberal and institutionalism theories. Within these vortex of philosophy and theories of development, have emerged what we may define as the combined theory and philosophy from African development scholars which is home-grown, pro-Africa, pro-poor, pro-growth and empirically based.

For over three decades, these Africans have labored to come up with a new development concept which is truely African with a pro-people and pro-poor approach that can genuinely answer the problems of underdevelopment in Africa. It is a result of the new shift in development theory from the old eurocentric models of defining development concerns for Africa and Africans that we have to situate this paper. What is development, then?

So rather than define development from any of the old theories, concepts or philosophical abstractism known to mostly western scholars or their academic adherents in Africa, I will rather pick from this new emerging field 
to which I am philosophically and theoritically attuned. (Samir Amin, 1974 \& Heinz Kimmerle, 1992: pp. 173-186).

Development is a multi-pronged and multi faceted process. It is a concept which enjoys a lot of philosophical, economic, social, political, educational, cultural, infrastructural patronage and dimensions support. It is human and people related in the sense that it is people defined, culturally related, people driven, dynamically exposed to their cosmology and ethnography. Every philosophy of development is therefore culturally and politically bound since it arises from the cultural milliue of its exponents and only relevant in that particular environment. To export it to other cultures is a tragic exercise in transformation; there can only be an acculturation interchange whereby peoples of all cultures sit down to assimilate and intergrate wholesome concepts acceptable to all mankind to define a collective global framework. Such a dialogue has not taken place, except in the realms of religion.

Development is therefore a homegrown capability of a given indigenious people to use its resources to fulfil their scio-economic, political and environmental challenges in a sustainable manner, with or without external assistance. Self reliance and cultural intergrity is at the heart and soul of true and genuine development. This concept fits the search, today, for explanations why Nigeria's economic development strategy known as NEEDS did not galvanize our people into participatory development and why we are looking for new inputs into the design of the second document called NEEDS 2. NEEDS has failed as development planning template to answer the problems of undervelopment and poverty in Nigeria because it was molded from the old eurocentric theoritical framework which is anti-Africa and Africans. To build the second development document, we should draw our development chart from the new African development framework which is pro-African people. To do so succesfully, we must expand the frontiers of consultation and negotiation on issues of development, involving stakeholders in development, down to the grassroots.

The need for a grassroots outreach and participation further explains why this re-evalauation of the role of the church in development is very germane to the intention of government to rewrite the document on poverty reduction in Nigeria. To rewrite that document as develop planing template we must invlove the church.

\subsection{Poverty Reduction-Defining and Measuring Poverty}

Internationally, poverty is frequently defined according to monetary income. But this is unafrican. The conception cannot capture the true reality of poverty in the continent. In this view, the poor are those who fall short of an income threshold or a certain amount of expenditure for consumption. But we know as we are assembled here today at Nekede that in Nigeria poverty has a broader cultural perspective as more than low income or low expenditure. It is seen broadly as the denial of opportunities and choices most basic to human development to lead a long, healthy, creative life and to enjoy a decent standard of living, freedom, dignity, self-esteem and respect from others (Stats SA). Interestingly enough, Monsignor Professor Obiora Ike (2005: p. 23), in his work "christianity and the scandal of the african continent", a paper he presented at the American Catholic Bishops Conference titled, "A call to Solidarity with Africa" as an african cultural economics exponent has a refreshingly relevant view here:

"The map of Africa tilted a little, looks like a question mark. This may be a geophysical or tectonic accident. Nevertheless, the contemporary African situation has been a real question mark on, and a huge scandal to the Christian faith. A continent sunk in doubts and debts cannot be anything short of a scandal to the liberative incarnation of the Godman. Our poverty cannot be explained nor resolved, even as a huge exisential question without us, without our culture, without the church".

The Poverty and Inequality Report prepared for the south African Presidency in (May, 1998) defined poverty as the inability to attain a minimal standard of living, measured in terms of basic consumptive needs or the income required to satisfy them. Poverty was seen to include alienation from the community, food insecurity, crowded homes, usage of unsafe and inefficient forms of energy, lack of adequately paid and secure jobs and fragmentation of the family (Poverty Report, South Africa, 1998: p. 23) The influences that must define our poverty in Nigeria must be culture and church driven. Interviews, consultations and workshops must be held to give a faith and culture based evaluation and measurement of the extent and depth of poverty in Nigeria for any poverty reduction strategic document to work. Professor Ike gave what I might call an African economic conception of poverty with multiple dimensions as follows: 
1) Security and Peace of mind

Physical and emotional insecurity, lack of safety net, lack of resources and opportunities. Not knowing where to find information, money, food and jobs.

2) Gender Relations

Unequal opportunities for women within training programs, discrimination in job opportunities.

3) Institutions

Lack of integration of communities, minimum integration of Government at all levels, lack of synergy amongst various stakeholders, lack of an empowered leadership.

4) Social Relations

Discrimination, rejection within society, deprivation within education system and isolation.

5) Capabilities

Lack of information, education, skills, human capacity, self-esteem, confidence and inability to take responsibility.

6) Vulnerability

Risk of health, under-nutrition, death, youth, aged, and dependency ratio on elderly, substance abuse.

7) Spatial

Spatial distribution and inequality, lack of access, distance to service delivery and jobs.

8) Physical

Hunger, exhaustion, under-performance.

9) Income and Assets

Income insecurity, seasonal inadequacies, lack of access to resources.

10) cultural

Cultural oprression, harrasment of indigenious cultures, destruction of indigenious knowledge and folkore, culturala and herbal piracy by foreign companies and lackof acceptance for other traditions and religious view

(Obiora Ike:27)

Professor Ike's cultural conception of poverty reflects similiarities with the views expressed by other authentic african scholars contemporary with him, such as the definition by the south african west coast scholars:

1. Psychological dimensions of poverty. 2. Poverty and ill health.

3. Impact of migration on poverty. $\quad 4$. Material well-being.

5. Basic infrastructure.

6. Need for literacy.

7. Lack of Social Inclusion.

8. Lack of integration (Obiora Ike:12).

\subsection{NEEDS, SEEDS, LEEDS and FEEDS}

We have freely used these concepts earlier without defining them. These are what are called the poverty reduction-strategic papers created by government and became operational in 2003 as Nigeria's strategic development planning instrument which was adopted at the national, state and local government levels. When the Centre for peacebuilding and poverty reduction studied the NEEDS document, we made an in input into it which should cater for the socio-economic needs of the family households; but this input was not incorporated into the policy. This explains why, despite the 8 years obasanjo tinkered with the economic reforms the average poor families in Nigeria, who are $70 \%$ of the population, did not fare better than before. The centre for peacebuilding and poverty reduction came up with the "parrew model for poverty reduction" which incorporates and situates the welfare of the family as the thrust of all poverty reduction schemes and strategies in Nigeria. It was part of the thoeritical framework of Parrew that we submitted what came to be known as FEEDS-Family economic empowerment development strategy. But government did not take this; but came out with NEEDS-National economic empowerment development strategy; SEEDS—State economic empowerment development strategy; and LEEDSLocal government economic empowerment development strategy. In designing these development documents government solidly avoided the involvment of the church which is pro-people and pro-poor institution that had been committed to development concerns as part of its christian mandate. Having explained the theoritical foundations of the key concepts in the body of the presentation, we shall go into the paper proper. 


\section{The Dual Role of the Church in Development and Poverty Reduction}

The church has a dual role in development. The first mandate is spiritual-to cater after the spiritual growth of its wards; the second is social, and it concerns catering to physical and societal needs of man, the development of his potentials for self actualization and the creation of an equitable and just environment for peace and justice to reign.

We need to appreciate the fact that the church is more than just the building that houses people for mass and other catetichal activities. To many people, the church means just a large building where people go to pray and receive the good news of Christ. However, the main thrust of my paper attempts to achieve a wider vision and conception of the church which contains its material role in driving pro-people and pro-poor development. The church carries out these functional roles in development when its leadership uses faith-based vehicles [FBVS] in planning and working within communities to reduce poverty; combining faith work with practical involvement in the lives of the poor (Ani, 2003: p. 18). A reflection of the pristine view of the church's role given by Jesus Christ himself sees it as "preaching the good news, freeing captives, giving sight to the blind and bringing justice to those who were oppressed. The spirit of Gaudium et Spes (Gaudium et Spes, 2008: p. 45) fully embodies this balanced role:

"The joy and hope, the grief and anguish of men of our time, especially of those who are poor or afflicted in any way, are the joy and hope, the grief and anguish of the followers of Christ as well".

The church is structurally designed with its development chains of contact and affiliations to know what the problems of the poor is and work in a participatory manner in working for change and development that will impact positively upon the people, especially those at the grassroots. No other institution, except other NGOS, is as powerfully positioned to work for a pro-people and pro-poor growth and development which will benefit the people. To leave them outside the government's development planning and implementation is to exclude from development the greater population of people at the basest level of poverty and underdevelopment.

But we need to internalize this role of the church in development and evolve a strategic plan to be more intergrative of the church in national and international development. In Colombia for example, the poverty reduction strategic development document was written with full church involvement and it bore the true marks and measures of poverty and its features in that country. Not only that, the Colombian government is equally implementing and monitoring the programs and projects with full enlistment and empowerment of the church and other members of the civil society in that country. The same church coalition, using the catholic development chain, is driving pro-poor and pro-people development with the active motivation of the governments of these countries. But what is the experience in Nigeria?

The main poverty reduction plan of the government of Nigeria is contained in the NEEDS document and, sure enough, the poor in Nigeria are still crying because, contrary to government propaganda, NEEDS is not solving peoples needs and the destitution of poverty is still worsening by the day in the country. Rather than reduce and alleviate poverty, NEEDS was, instead, increasing it. The main culprit has been corruption. Corruption of the concept, formulation, execution and evalauation of impact of the NEEDS. Why is the document not working? In 2007, here in owerri, at Imo concorde hotel, I represented the Catholic Institute for Development Justice and Peace-CIDJAP, to brainstorm with the officers of the National Planning Commission on why the document is not working and what could be done by stakeholders to design a second document which could be used for development planning in Nigeria. My views remain the same:

"The civil society was not fully involved in the planning, formulation and execution of NEEDS 1; people see it as government business. How could you reduce poverty in Nigeria, without involving institutions like the church which had been living and working together with the poor for as long as over ten decades in the country? While I would not say outrightly that the first document failed because of the non-invlovement of the poor, I would agree with others that one of the main reasons for failure was because of the non-involvement of the faithbased vehicles for poverty reduction and development. It was because of this non-involvement that corruption became a sesame for siphoning government's budgeted resources meant for poverty reduction programs and sabotaging policies targeted at the Nigerian poor....” (The NEEDS Document, National Planing Commission Abuja, 2002).

Government would not want the involvement of the church since the church will not condone corruption within the system created for poverty reduction in Nigeria (The Week Magazine, 2008: p. 6). The involvement 
of the church in poverty reduction activities in Nigeria will certainly empower the people and hence result in development benefits to the nation. The church would have assisted enormously in mobilizing the people to define what are the problems: programs, projects and vision of development. This would give development scholars to test out the new African development framework which is essentially pro-people. If we have used government organs in the past and this has failed bring about genuine development, why don't we try out the new framework which has been tried and tested through the catholic development framework?

Seeing how partnership works will ginger African leaders to have the courage and vision to bring into the development context other faiths. It is against this theoritical framework and explanatory platform of the key words involved in this paper that I go further to explore the main thesis of this paper.

\section{Nigeria: The State and the Situation of Poverty}

Years of military rule in Nigeria have brought about economic underdevelopment, anomie, atrophy, corruption and outright destitution in the standard of living of Nigerians with our people almost eating out of the dustbins. President oluseguna obasanjo and his economic team, after consulting with peripheral stakeholders throughout Nigeria, came up with the National Economic Empowerment and Development Strategy (NEEDS) as the response to the development challenges of Nigeria. In 1999, most people grossly underestimated the extent of social, political, and economic decay of the country. Part of the objectives of the NEEDS is to stabilize the polity, consolidate the democratic governance structure, make realistic progress in the social and economic spheres which will lead to poverty reduction in real terms. Over the next few years (2003-07), NEEDS attempted to consolidate the achievements of the previous four years and lay a solid foundation for sustainable poverty reduction, employment generation, wealth creation, and value reorientation. Our country Nigeria is blessed with all the human and material resources to become one of the 20 strongest economies in the world and the most dynamic in Africa. As a development strategy, NEEDS vision is indeed laudable since it sets out to mobilize the resources of Nigeria:

"To make a fundamental break with the failures of the past and bequeath a united and prosperous nation to generations to come... a home-grown reform programme... an extensive consultative and participatory process, involving major stakeholders in the design of NEEDS. It is this national ownership, that will ensure the sustainability of the NEEDS beyond 2007....” (The NEEDS Document, National Planing Commission Abuja, 2002)

But we know too well that much as the design of the documents went through some measure of participatory process which saw the inputs of some stakeholders deemed as the "experts in economic theory", the implementation and the evaluation process did not have any pro-people involvement and full participation. Moreover, the documentation suffered so much in its implementation that the goal of poverty reduction in real terms was not achieved. Infact, Nigerians, after eight years of NEEDS implementation, felt that economic reforms had a negative impact upon them. Though inflation went down to single digit figures, economic stability was attained in growth terms, development, in real terms, was deficient.

So what went wrong with NEEDS1? This gives us a lot of verve and moral justification to re-examine the document and make for a fresh beginings by going back to development theory to know what went wrong. In the first place the document was fostered by Breton woods and fuelled by the old eurocentric theory of development which does favor Africa entirely. As we all know, it is only bad plans that do not allow for periodic amendments. NEEDS is supposed to be a living document, and aspects of it may be modified in the light of implementation experiences.

\subsection{The Church Dialoguing with the People on African Development}

The new African approach to development concerns is pro-people in definition and participation in developemnt concerns and in its processes. It is later that we can understand why the church will encourage this pro-African methodology as a result, among others, of its current efforts to dialogue with culture and its people in Africa. I have decided to restrict my focus on what needs to be done to mobilize the church so as to be fully involved in the fundamental task of reducing poverty in Nigeria.

The Nigerian church has been involved in national development since independence. The church has been involved and committed through its different faith-based vehicles which include but not limited to Caritas, jus- 
tice and peace commission, CIDJAP, Catholic Relief Services, The Club of Rome etc. The church has through the works of different congregations built and successfully managed hospitals, schools, orphanages, hospices, rural health centres, and microfinance banks. It is my view that the church in Nigeria must become proactive in poverty reduction and development matters in Nigeria. The FBVS are creations by the church to reduce poverty, establish justice, peace and intergral development in the country. The government needs to empower the church's FBVS to carry on and participate fully in designing the strategy for poverty reduction; implementing it and evaluating the impact of its policies upon the poor. This mobilisation plea will rest upon what I might define as my canons for successful involvement of these fbvs. What are these canons?

\subsection{Public Perception of the Role of the Church in Development}

How do we see the Church today? The outdated and fossilized perception we have of the Church in state and people development has fostered a cold and non-involved participation and non-invitation by the state in development matters. We must re-evaluate the way we see the church. In the past, it used to be an image of a church which is passive, quiet and always reacting to issues after they have taken place. We must become proactive and positive by designing new strategies to study the problems of development and how we must make development work for the people of Nigeria. The Enugu catholic docese has a growing pro-people and pro-poor microfiance initiative which has the financial empowerment of the diocesan poor as its cardinal objectives. It is known as the umuchinemere pro-credit microfinance bank which was designed by poor people drawn from all the parishes in the diocese; the execution was done overtime by the same people elected by their people from the diocese but from within the urban and village communities. The same people turned out on the day the Bishop of Enugu commissioned the bank with prayers to empower it to serve the people who own it. The bank's microfinance motto is "making money work for the poor". The lesson in this project design and execution is that there is no way government can design a poverty reduction project without the involvement of the people it meant to serve.

People define their developemnt needs and challenges; they define who to partner with and how to implement their development plans. At the end of the day, they are the ones who can tell whether developemnt has actually taken and they have benefited or not. Eurocentricism imposes developemt upon people but the new african modernisation theory allows people to determine culturally what happens to them. The church is a proven reliable ally in assisting people to have the final say on development that concerns their lives. Tapping the energy and synergy of this collective chain of developement is the main thrust of my argument.

There is a clinical efficiency, moral throughness and discipline which runs through the management of such vehicles which flower the development potentials and energies of the people. The church has proven to be a people mobilizer for growth and development concerns. Other faiths have their own faithbased vehicles which have suceeded in defining and driving a pro-people development in their environments in ways which avoid corrupt and greedy tendencies of government project managers.

A good example of another faith based vehicle for poverty reduction is the concept of Seva which is introduced by the devotees of Bhagavan Sathya Sai Baba, an indian guru who gives free medical services to poor people in all the countries where his humanitarian concept of hospital delivery is accomplished with selfless elan and love. Government does not give his project even one rupee, but in a small way, he has succeeded in achieving the aims of the United Nations Health delivery to all than could all the huge billions siphoned away through civil servants who manage our health systems every year. Yet, it is only the faithfuls of his faith who give a freewilled donation as it touches them.

The church's concept of Caritas is a good correspondence to this theory made popular globally as sevaselfless and egoless service to the poor without expectations of any pay!

\subsection{Dynamize the Concept of the Kingdom Service into Caring for the Poor}

Serving the kingdom means more than preaching-we must intergrate the challenges of caring for the Nigerian Poor by carrying out statistical profiling of the problems of poor people in our environment and advocating for them before governments. This will make poor people to value the church more and empower the church even more in the eyes of governments as an instiution that understands the real needs of the poor.

\subsection{Meeting the Challenges of Leadership in Nigeria}

The problem of Nigeria is leadership and the church is running away from it. The church has a biblical model of 
leadership in Jesus christ. The church in Nigeria must start a school for the preparation of God fearing and incorruptible leaders from its rank and file. The model here is the concept of servant leadership who can identify, support and support others to participate fully in development in their communities and states. What is the immediate implication of this, for this forum? In the first place, we must develop our leadership skills; two, listen to others as they contribute to development issues; develop facilitation skills of our clergy and laity.

\subsection{Set up Small Cordinating and Action-Learning Groups Nationally to Study Poverty in Nigeria}

The work of this group will be to:

1) integrate church values within pro-poor and pro-people programs in the context of new challenges in NEEDS2;

2) Represent the situational report of rural communites in their development challenges and problems;

3) Bechmarking for best practices on cultural african development;

4) Planning and capacity building for growth and expansion of fbvs

5) Dealing with emergency problems of inter religious dialogue and conflict resolution in Nigeria;

6) Finally, maintaining the vision with sustainable enthusiasm from the parishes to the local, state and national levels of the economy.

\section{Creating the Partnership between Governments and the Catholic Development Chain}

At this point we can see the direction this paper is driving towards-we are exploring "the meaning and function of partnership within the catholic church development chain (Mores \& Macnamara, 2007: pp. 65-78).

One of the critical features of this chain is the role played by the fbvs which emphasizes "shared beliefs and morality which stresses tolerance, respect for neighbor and a need to listen... and does succeed in bringing about more and better change” (Mores \& Macnamara, 2007: p. 79).

Three distinct thrusts emerge after analysing this catholic development chain in Nigeria as defined by Stephen and Macnamara. These thrusts are the pillars that drive development: Power, Interdependency and Performance. They are also the principles used by the faith based organisations to mobilize the people and bring about real and measurable development benefits to the people. It is critical that we should explore the essence of this new developement trinity further as it will help us to contextualize the role of the church in poverty reduction in our conclusion.

\subsection{Power}

This refers to the base of power-the resources used to bring influence; means of power-actions to be taken to bring about influence; scope of power-specific actions taken to bring about influence; and amount of power-the extent of the influence. The power analytical forum leads to programs, practices and accountability on how power is used;

\subsection{Interdependency}

Every key stakeholder is dependent upon each to enable and drive development solutions, solve problems like poverty and injustice with an eye for longterm planning. This will eliminate selfishness and bring the cultural ethos of communalism or other-centredness to development planning.

\subsection{Performance}

We learn to establish evidence-based measuring for impacts and not rethoric and government propaganda. Only when poverty reduction programs and strategies succeed and uplift people can we say they have succeeded in Nigeria. The implication is that we will always look for outcomes and positive impacts upon the sufferings of the faithful in Nigeria. These three pillars define the catholic development chain which could be placed at the disposal of government to define the framework for pro-people and pro-poor development in the country. It will form the heart and self partnership between the government, the church, civil society and the poor people of 
Africa and Nigeria.

\section{Conclusion}

Need we say more than the fact that we are not using enough of the resources and potentials of the church, such as the numerous faith based vehicles, to solve development problems such as poverty in the land. We must together design poverty reduction strategies which will fully exploit the power, interdependency and performance capabilities of our development chain involving governments, multilateral agencies, catholic donors agencies, catholic educational projects such as FBVS, individuals, households, communities and special groups. Thanks and God bless.

\section{References}

Ake, C. (2003). Democracy and Development in Africa, Abuja. Ibadan: Spectrum Books Ltd., 1-17.

Amin, S. (1974). Philosophy and Development in an African Context-A Recent Attempt to Understand the Notion of Development in a Philosophical African Context. In H. Lauer (Ed.), History and Philosophy of Science. Ibadan: Hope Public.

Ani, C. (2003). Re-Evaluating the Role of the Church in Poverty Reduction and Reforms in Nigeria-Cidjap's Fbvs Models-Lecture. The DFID Lecture Series/Seminar, Enugu, 3 Febuary 2003.

Ani, C. (2012). PHILARA—A New Approach to the Study of Philosophy as a Practical Science of Research and Society. Kaduna: West \& Solomon Publishers.

Gaudium et Spes (2008). No. 1. Rome: Vatican Press.

Hans, R. (1967). Re-Evaluating Thomas Khun and Paradigm Paradox. New York: Telhard Publications.

Himmelstrand, U. et al. (1994). This Is a Big Challenge-In Search of a New Paradigm. New York: St Martins Press.

Ike, O. (2005). Christianity and the Scandal of the African Continent. The American Catholic Bishops Conference, A call to Solidarity with Africa.

May, J. (1998). The Poverty and Inequality Report Prepared for the South African Presidency.

Mores, \& Macnamara (2007). Creating a Greater Partnership:Analysing Partnership in the Catholic Church Development Chain. Journal of Royal Geographic Society, 1, 65-78.

The NEEDS Document, National Planing Commission Abuja (2002) The National Economic Empowerment and Developement Document-NEEDS. Abuja: National Planing Commission.

The Week Magazine Editorial (2008). Corruption Incorporated-How Obasanjo and Co. Ruined Nigeria. Nigeria: Sahel Press. 
Scientific Research Publishing (SCIRP) is one of the largest Open Access journal publishers. It is currently publishing more than 200 open access, online, peer-reviewed journals covering a wide range of academic disciplines. SCIRP serves the worldwide academic communities and contributes to the progress and application of science with its publication.

Other selected journals from SCIRP are listed as below. Submit your manuscript to us via either submit@scirp.org or Online Submission Portal.
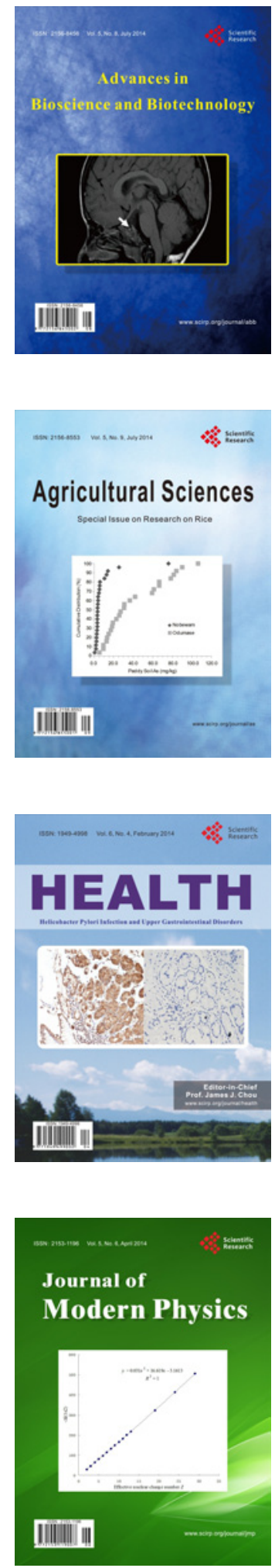
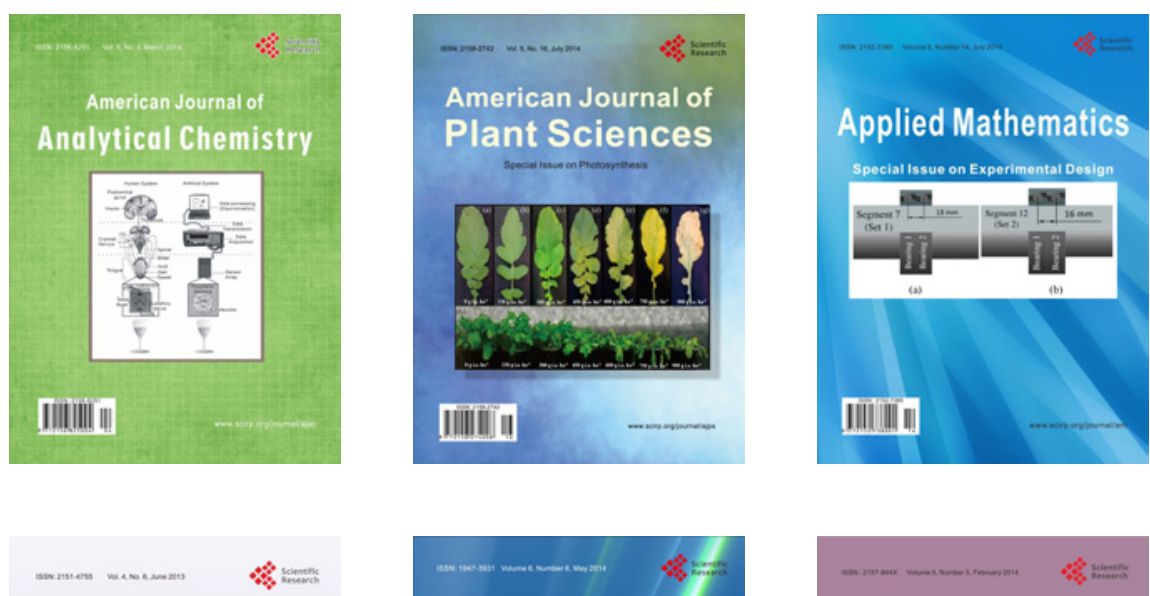

Creative Education
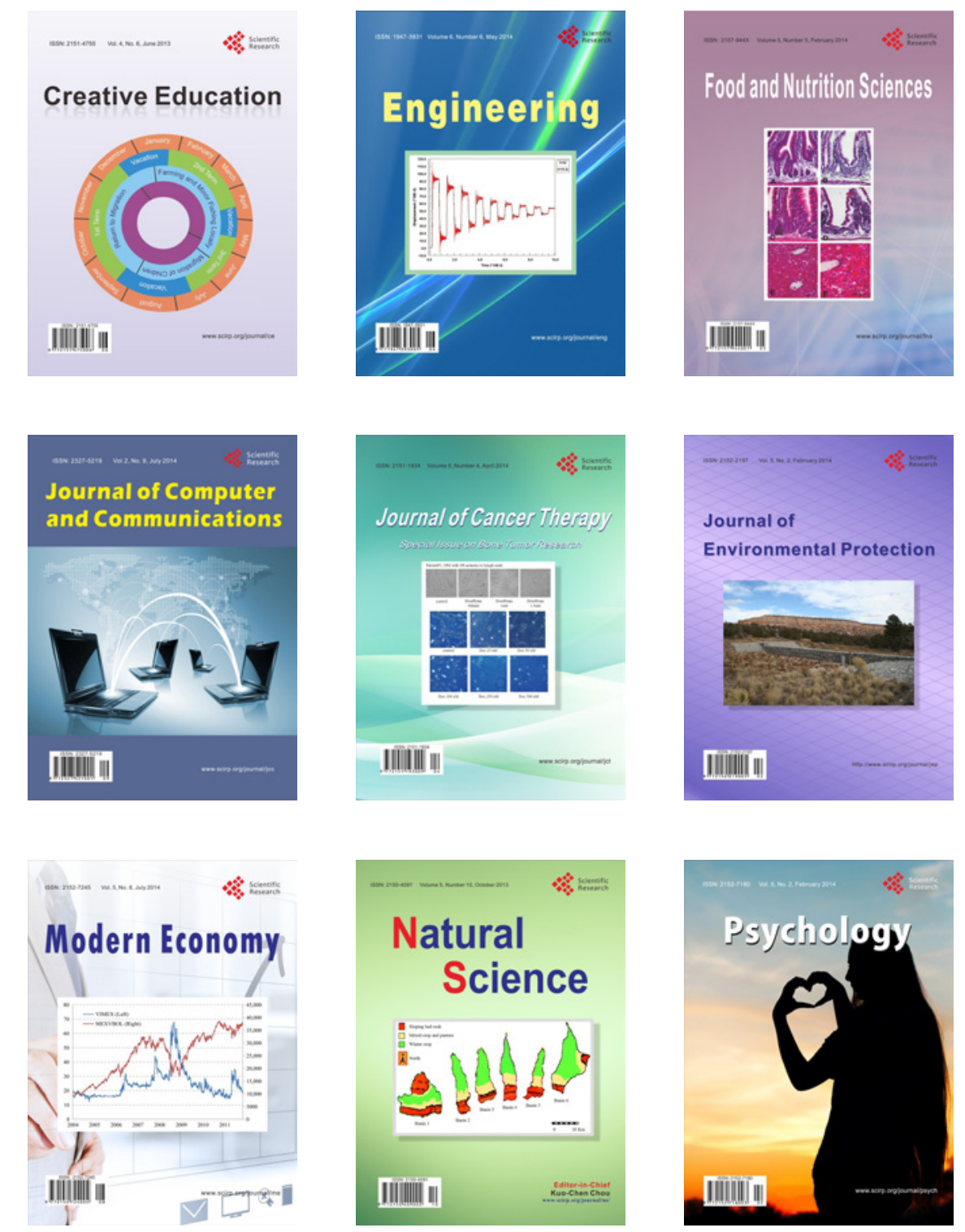